\title{
Outcome after mitral valve surgery for functional mitral regurgitation in idiopathic dilated cardiomyopathy
}

\author{
V Shumavets,', A Ostrovski, I Andraloits, S Kurganovich, I Grinchuk, D Romanovski, O Jdanovich, Y Ostrovski \\ From 23rd World Congress of the World Society of Cardio-Thoracic Surgeons \\ Split, Croatia. 12-15 September 2013
}

\section{Background}

To assess the outcome of surgery of functional mitral regurgitation (FMR) in idiopathic dilated cardiomyopathy (IDCM).

\section{Methods}

We retrospectively investigated 146 patients (131 men, 16 women; mean age, 67 years) with severe functional mitral valve (MV) insufficiency due to dilated cardiomyopathy that were operated on between 2004 till 2012. 35 pts were in New York Heart Association class IV and 102 were in class III. Most of pts had severe enlarged LV (mean end-diastolic size $73.7 \pm 7,1 \mathrm{ml}$ and volume 293 $\pm 80 \mathrm{ml}$ ) with depressed systolic function (mean ejection fraction $-26.1 \pm 5,6 \%$ ). Concomitant procedures were tricuspid repair (139 pts) and atrial fibrillation ablation (32 pts). In 35 pts (24\%) epicardial LV lead was fixed with subsequent CRT implantation during the same hospitalization. Mitral valve annuloplasty with different types of undersized ring were performed in 101 patients, and 45 had mitral valve replacement (in 6 pts mechanical and in 39 pts biological).

\section{Results}

There were no perioperative deaths, in 2 pts BiVAD were started due to inability to wean from CPB. 4 patients (2.7\%) died within 30 days postoperatively. Overall freedom from $M R \geq 2+$ was $96.1 \%$. Both $L V$ end-diastolic and end-systolic volumes indexed significantly decreased (both $\mathrm{p}=0.0001$ ). After MV repair ejection fraction increased from $25.2 \pm 7,5 \%$ to $29,2 \pm 9,4 \%(\mathrm{p}=0,04)$. The mean follow-up was $47.6 \pm 4.1$ months. 1-years survival was

* Correspondence: Vshumaviec@gmail.com

Cardiac Surgery Department, Belarus Cardiology Centre, Minsk, Belarus
$78 \pm 0.04 \%$, 5 -years - $39 \pm 0.08 \%$. The fact of mitral valve replacement versus repair did not influence survival (longrank $\mathrm{p}=0,145)$. The type of ring used for annuloplasty not influenced survival (long-rank $\mathrm{p}=0.37$ ). Statistical analysis identified preoperative NYHA class as predictor of long-term survival (hazard ratio (HR) 4.53, 95\% CI 2.7$13.5, \mathrm{p}=0.004)$.

\section{Conclusion}

Despite high operative risk in patients with IDCM, mitral valve surgery can be performed successfully with acceptably low hospital mortality, clinical improvement and a moderate recovery of $\mathrm{LV}$ function.

Published: 11 September 2013

doi:10.1186/1749-8090-8-S1-0292

Cite this article as: Shumavets et al:: Outcome after mitral valve surgery for functional mitral regurgitation in idiopathic dilated cardiomyopathy. Journal of Cardiothoracic Surgery 2013 8(Suppl 1):O292.

Submit your next manuscript to BioMed Central and take full advantage of:

- Convenient online submission

- Thorough peer review

- No space constraints or color figure charges

- Immediate publication on acceptance

- Inclusion in PubMed, CAS, Scopus and Google Scholar

- Research which is freely available for redistribution

Submit your manuscript at www.biomedcentral.com/submit C Biomed Central

\section{Biomed Central}

(c) 2013 Shumavets et al; licensee BioMed Central Ltd. This is an Open Access article distributed under the terms of the Creative Commons Attribution License (http://creativecommons.org/licenses/by/2.0), which permits unrestricted use, distribution, and reproduction in any medium, provided the original work is properly cited. 